\title{
Effective Learning, Leadership and Professionalism Series (ELLPS) nurturing early clinical year development: Transformation based on medical students' feedbacks.
}

Research article

Keywords:

Posted Date: November 17th, 2020

DOl: https://doi.org/10.21203/rs.3.rs-25752/v2

License: (1) This work is licensed under a Creative Commons Attribution 4.0 International License. Read Full License 


\section{Abstract}

The authors have requested that this preprint be withdrawn due to erroneous posting.

\section{Full Text}

The authors have withdrawn this preprint from Research Square. 